\title{
Context Dependent Role of Type 2 Innate Lymphoid Cells in Allergic Skin Inflammation
}

\author{
David A. Rafei-Shamsabadi i*, Christoph S. N. Klose ${ }^{2}$, Timotheus Y. F. Halim ${ }^{3}$, \\ Yakup Tanriver ${ }^{4,5}$ and Thilo Jakob ${ }^{6 *}$ \\ ${ }^{1}$ Allergy Research Group, Department of Dermatology, Medical Center-University of Freiburg, Faculty of Medicine, University \\ of Freiburg, Freiburg, Germany, ${ }^{2}$ Laboratory of Innate Immunity, Department of Microbiology, Infectious Diseases and \\ Immunology, Charité-Universitätsmedizin Berlin, Berlin, Germany, ${ }^{3}$ CRUK Cambridge Institute, University of Cambridge, \\ Cambridge, United Kingdom, ${ }^{4}$ Institute of Medical Microbiology and Hygiene, University Medical Center Freiburg, Freiburg, \\ Germany, ${ }^{5}$ Department of Internal Medicine IV, University Medical Center Freiburg, Freiburg, Germany, ${ }^{6}$ Experimental \\ Dermatology and Allergy Research Group, Department of Dermatology and Allergology, University Medical Center Giessen, \\ Justus Liebig University Giessen, Giessen, Germany
}

\section{OPEN ACCESS}

Edited by:

Marina Cella,

Washington University School of Medicine in St. Louis, United States

Reviewed by:

Stanley Ching-Cheng Huang, Case Western Reserve University, United States Christoph Wilhelm,

University of Bonn, Germany

*Correspondence:

David A. Rafei-Shamsabadi david.rafei-shamsabadi@ uniklinik-freiburg.de Thilo Jakob

thilo.jakob@derma.med.uni-giessen.de

Specialty section:

This article was submitted to NK and Innate Lymphoid Cell Biology,

a section of the journal

Frontiers in Immunology

Received: 12 May 2019 Accepted: 18 October 2019 Published: 06 November 2019

Citation:

Rafei-Shamsabadi DA, Klose CSN, Halim TYF, Tanriver Y and Jakob T (2019) Context Dependent Role of

Type 2 Innate Lymphoid Cells in Allergic Skin Inflammation.

Front. Immunol. 10:2591. doi: 10.3389/fimmu.2019.02591
The discovery of innate lymphoid cells (ILC) has profoundly influenced the understanding of innate and adaptive immune crosstalk in health and disease. ILC and T cells share developmental and functional characteristics such as the lineage-specifying transcription factors and effector cytokines, but importantly ILC do not display rearranged antigen-specific receptors. Similar to T cells ILC are subdivided into 3 different helperlike subtypes, namely ILC1-3, and a killer-like subtype comprising natural killer (NK) cells. Increasing evidence supports the physiological relevance of ILC, e.g., in wound healing and defense against parasites, as well as their pathogenic role in allergy, inflammatory bowel diseases or psoriasis. Group 2 ILC have been attributed to the pathogenesis of allergic diseases like asthma and atopic dermatitis. Other inflammatory skin diseases such as allergic contact dermatitis are profoundly shaped by inflammatory NK cells. This article reviews the role of ILC in allergic skin diseases with a major focus on ILC2. While group 2 ILC are suggested to contribute to the pathogenesis of type 2 dominated inflammation as seen in atopic dermatitis, we have shown that lack of ILC2 in type 1 dominated contact hypersensitivity results in enhanced inflammation, suggesting a regulatory role of ILC2 in this context. We provide a concept of how ILC2 may influence context dependent the mutual counterbalance between type I and type II immune responses in allergic skin diseases.

Keywords: innate lymphoid cells, allergic contact dermatitis, atopic dermatitis, counter regulation, immune crosstalk

\section{INTRODUCTION}

Innate lymphoid cells (ILC) are innate immune cells of the lymphoid lineage, which have a similar functional diversity as $\mathrm{T}$ cell subsets based on the developmental dependency on lineage-specifying transcription factors and effector functions. Like T and B lymphocytes, all ILC derive from a hematopoietic stem cell-derived common lymphoid precursor (CLP) cell in the bone marrow (Figure 1). The CLP gives rise to an early innate lymphoid precursor (EILP) that expresses the transcription factor (TF) T-cell factor 1 (Tcf-1). From this branching point natural killer (NK) 
cells develop via a NK precursor (NKp) and by upregulating the TFs eomesodermin (EOMES) and T-box transcription factor TBX21 (T-bet). The other branch develops into an Id2 expressing common helper-like ILC progenitor (CHILP). C-C chemokine receptor type 6 positive $\left(\mathrm{CCR}^{+}\right)$ILC3 can directly evolve form the CHILP depending on the expression of RAR-related orphan receptor (ROR) $\gamma$ t. All the remaining helper-like ILC subtypes, namely ILC1, ILC2, and ILC3, evolve from an innate lymphoid cell precursor (ILCP) which expresses the TF promyelocytic leukemia zinc finger (PLZF). CCR6 ${ }^{-}$ILC3 can adapt a more ILC1-like phenotype by downregulating ROR $\gamma \mathrm{t}$ and upregulating T-bet. These cells are called ex ILC3. Production of their marker cytokines attributes certain physiological and pathological roles to the particular ILC subtype (Figure 1). Effector ILC can be classified into three interleukin-7 receptor positive (IL-7R ${ }^{+}$) helper-like ILC groups (ILC1-3) and one IL-7R ${ }^{-}$cytotoxic ILC group (NK cells) (1-3). More recently, several groups have also identified IL-10 secreting ILC with proposed regulatory functions (4-6). Helper-like ILC and NK cells are mainly populated at barrier surfaces like the skin, gut, and the respiratory tract, although significant numbers can be detected in secondary and tertiary lymphoid organs in homeostasis and disease (7). Besides the bone-marrow, alternative sites of development exist, such as secondary lymphoid organs or even non-hematopoietic organs such as the gut (8-10). While ILC development continues throughout life, it is known that some ILC lineages are longlived, and seed their designated tissues early in embryogenesis as demonstrated by parabiosis experiments in mice that show only little replenishment of helper-like ILC from the bone marrow in later life (11-13). Although some helper-like ILC express homing receptors for certain tissues these cells are mainly thought to proliferate on site under proinflammatory conditions $(7,14)$. Given their localization at barrier surfaces ILC perfectly serve as sensors for danger signals but also allergens and subsequently mount early immune responses by rapid cytokine production. They can act as initiators of the adaptive immune response by crosstalk with dendritic cells and T cells finally shaping full blown type 1, 2, or 3 immune responses [reviewed in (15)]. This review

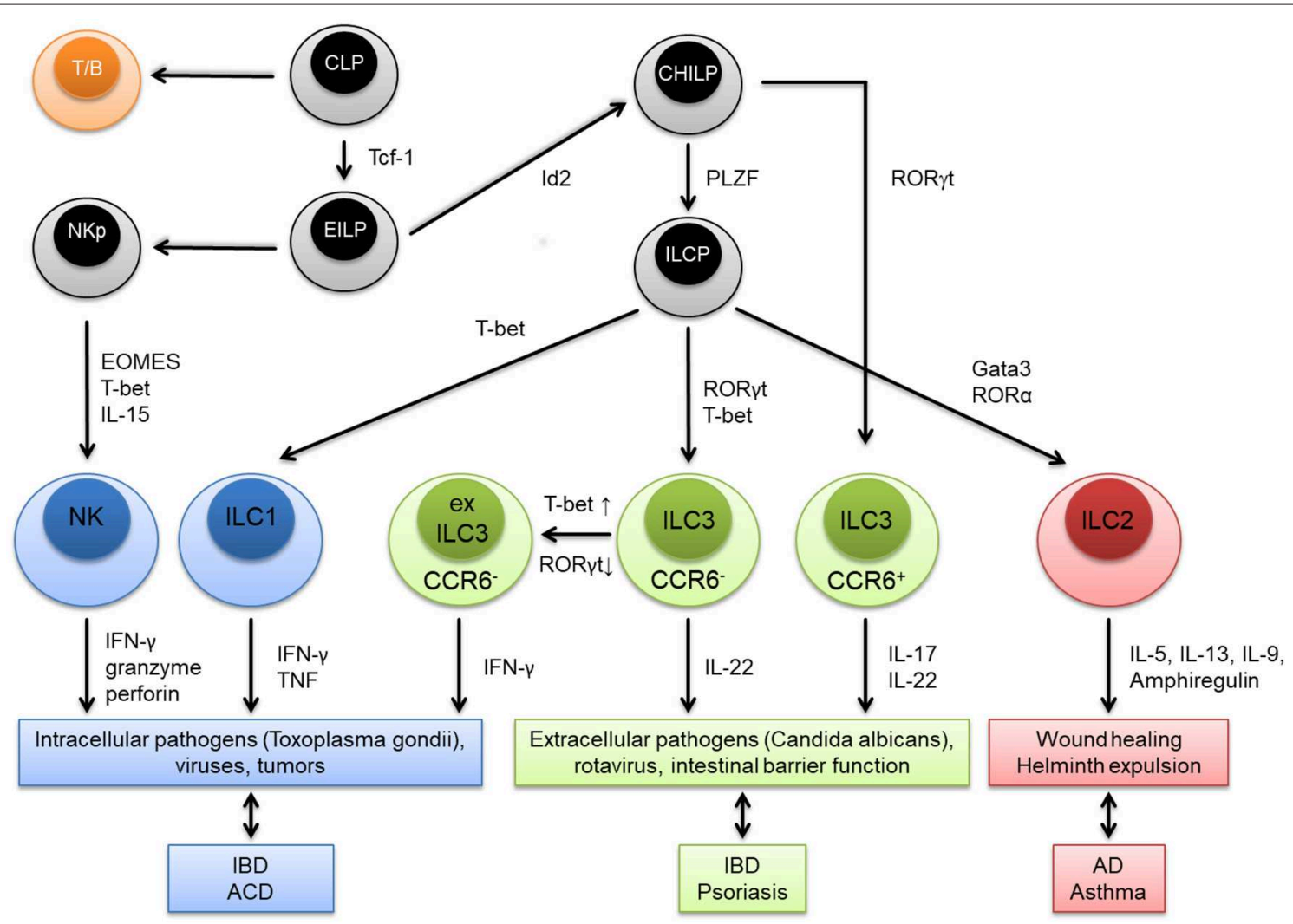

FIGURE 1 | Graphical summary of innate lymphoid cell (ILC) subtypes. ILC as well as T and B lymphocytes (T/B) derive from a common lymphoid precursor (CLP). The CLP gives rise to an early innate lymphoid precursor (EILP) that expresses the transcription factor (TF) T-cell factor 1 (Tcf-1). From this point natural killer (NK) cells develop via a NK precursor (NKp) and upregulate the TFs eomesodermin (EOMES) and T-box transcription factor TBX21 (T-bet). The helper-like ILC lineage derives from an Id2 expressing common helper-like ILC progenitor (CHILP) from which C-C chemokine receptor type 6 positive (CCR6 ${ }^{+}$) ILC3 can directly evolve depending on the expression of RAR-related orphan receptor (ROR)yt. All the remaining helper-like ILC subtypes, namely ILC1, ILC2, and ILC3, evolve from an innate lymphoid cell precursor (ILCP) which expresses the TF promyelocytic leukemia zinc finger (PLZF). CCR6 ${ }^{-}$ILC3 can adapt a more ILC1-like phenotype by downregulating ROR $\gamma$ t and upregulating T-bet. These cells are called ex ILC3. Production of their marker cytokines attributes certain physiological and pathological roles to the particular ILC subtype. IBD, inflammatory bowel disease; ACD, allergic contact dermatitis; AD, atopic dermatitis. 
highlights the pathogenic role of ILC in the allergic skin diseases with a main focus on ILC2.

\section{ILC CLASSIFICATION AND PLASTICITY NK Cells and ILC1}

NK cells are considered the innate counterpart of memory $\mathrm{CD} 8^{+} \mathrm{T}$ cells. They share similar functions such as cytotoxicity and interferon- $\gamma$ (IFN- $\gamma$ ) production and both express the transcription factors Eomes and T-bet. ILC1 on the other hand closely resemble $\mathrm{T}_{\mathrm{H}} 1$ cells. Both express and depend on $\mathrm{T}$ bet but lack EOMES and produce IFN- $\gamma$ (16-19). NK cells and ILC1 are involved in protecting the organism against pathogens, viruses and tumors $(16,20,21)$. Intraepithelial ILC1 can be found in Crohn's disease patients and contribute as a proinflammatory IFN- $\gamma$-producing population in an anti-CD40induced colitis model in mice (22). NK cells are suggested to be important in enhancing inflammatory responses in a hapten based contact hypersensitivity mouse model and human allergic contact dermatitis $(23,24)$. Taken together these cell types are mainly involved in mounting a type 1 immune response.

\section{ILC2}

ILC2, like $\mathrm{T}_{\mathrm{H}} 2$ cells, highly express the transcription factor GATA3 and produce type 2 cytokines including interleukin5 (IL-5), IL-13 and the epidermal-growth-factor-like molecule amphiregulin (7). ILC2 mediate pathology in a mouse model of atopic dermatitis and promote wound healing in an IL-33dependent manner $(25,26)$. ILC2 promote type 2 driven immune responses by promoting $\mathrm{T}_{\mathrm{H}} 2$ differentiation of naïve $\mathrm{CD} 4^{+} \mathrm{T}$ cells through production of IL-13, and by expression of MHC class II on their cell surface induce $\mathrm{T}$ cell priming (27-29). In addition, the inducible T-cell costimulatory (ICOS) molecule is highly expressed on ILC2 regulating their activation status and proliferation $(30,31)$. Moreover, activated ILC2 can express the TNF receptor superfamily ligand OX40L, which promotes local $\mathrm{T}_{\mathrm{H}} 2$ cell proliferation and adaptive type 2 inflammation (32). Increased ILC2 numbers are linked to human allergic airway and skin diseases like allergic asthma atopic dermatitis (25, 33-36). Thus, type 2 immune responses are profoundly shaped by ILC2.

\section{ILC3}

ILC3 share ROR $\gamma$ t expression with $\mathrm{T}_{\mathrm{H}} 17$ cells and can produce IL-17 and IL-22 thereby helping the organism to fight against bacteria and fungi and viruses, such as Citrobacter rodentium, Salmonella enterica, Candida albicans, and rotavirus (2, 7, 3741). There are ILC 3 expressing the chemokine receptor CCR6 which comprise lymphoid-tissue-inducer (LTi) cells and can be $\mathrm{CD} 4^{+}$or $\mathrm{CD}^{-}$. These cells are crucially important in the embryonic development of many lymphoid organs, whereas in adult mice they reside mainly in cryptopatches of the intestine with low proliferation (42-45). In mice, CCR6 $6^{-}$ILC3 can express natural killer cell receptor such as $\mathrm{NKp} 46\left(\mathrm{NCR}^{+}\right.$ILC3), loose ROR $\gamma$ t expression and upregulate T-bet, finally leading to IFN- $\gamma$ production (46-50). These "ex-ROR $\gamma \mathrm{t}^{+}$ILC3" closely resemble ILC1. A large population of ILC3 can be found in the intestine where they are essential for maintaining barrier integrity and immunologic tolerance to commensal bacteria of the gut (51-53). IL-17 producing ILC3 are proposed to be involved in plaque formation in a psoriasis mouse model based on the topical application of the Toll-like receptor 7 (TLR7) agonist imiquimod (54). Finally, elevated numbers of ILC3 are found in blood and affected skin of psoriasis patients (55-57). Given this data ILC3 are part of type 3 immune responses and intestinal immunopathology.

\section{ROLE OF ILC IN ATOPIC DERMATITIS}

Impaired barrier function of the skin is a hallmark in the pathogenesis of atopic dermatitis (AD). Loss-of-functionmutations in the gene coding for the epidermal structure protein filaggrin is strongly associated with an elevated risk to develop atopic dermatitis by allowing elevated trans epidermal water loss, higher prevalence of Staphylococcus aureus on the skin and facilitated penetration of allergens (58-61). The type 2 inflammatory response in $\mathrm{AD}$ is known to involve innate and adaptive immune cells like mast cells, eosinophils, and $\mathrm{CD} 4^{+}$ $\mathrm{T}_{\mathrm{H}} 2$ cells, the latter producing type 2 cytokines like IL- 4 , IL-5, and IL-13 (62). Since ILC2 are described in the skin (63) this led to the hypothesis that innate lymphoid cells, especially ILC2, may contribute to the pathogenesis of this frequently occurring atopic disease (Figure 2).

\section{ILC in Human Atopic Dermatitis}

Significantly more ILC2 can be found in lesional skin biopsies from patients suffering from atopic dermatitis in relation to skin from healthy individuals $(25,36)$. These ILC2 produce high amounts of the type 2 cytokines IL- 5 and IL-13 and express the membrane bound IL-33 receptor ST2 as well-receptors for IL25 and thymic stromal lymphopoietin (TSLP) $(25,36)$. These changes are even more profound when ILC2 are isolated from skin of house dust mite (HDM) allergic individuals that have been challenged epicutaneously with HDM extract. IL-33 is able to strongly enhance the expression of IL-13 and IL-5 and to increase the migratory capacity of isolated skin-derived ILC2 in vitro (36). Interestingly, ILC2 from atopic patients also express higher amounts of the killer cell lectin-like receptor G1 (KLRG1), which is even further elevated after stimulation with IL-33 or TSLP (36).

Human ILC2 express the prostaglandin $\mathrm{D}_{2}\left(\mathrm{PGD}_{2}\right)$ receptor chemoattractant receptor-homologous molecule expressed on $\mathrm{T}_{\mathrm{H}} 2$ cells $(\mathrm{CRTH} 2)(64,65)$. $\mathrm{PGD}_{2}$ which is mainly produced by mast cells induces ILC2 migration, production of type 2 cytokines and upregulation of the expression of IL-33 and IL-25 receptor subunits (ST2 and IL-17RA) in vitro (66). The effects of $\mathrm{PGD}_{2}$ on ILC2 can be mimicked by the supernatant from activated human mast cells (through IgE-mediated degranulation) and inhibited by a CRTH2 antagonist highlighting a cross-talk between mast cells and ILC2 (66).

ILC2 respond to further mast cell mediators like cysteinyl leukotrienes, particularly $\mathrm{LTE}_{4}$ (67). Human ILC express the functional leukotriene receptors $\mathrm{CysLT}_{1}$ and its expression is increased in patients with atopic dermatitis (67). LTE $_{4}$ not only induces migration, promotes cytokine productions 


\section{Role of ILC2 in atopic dermatitis}

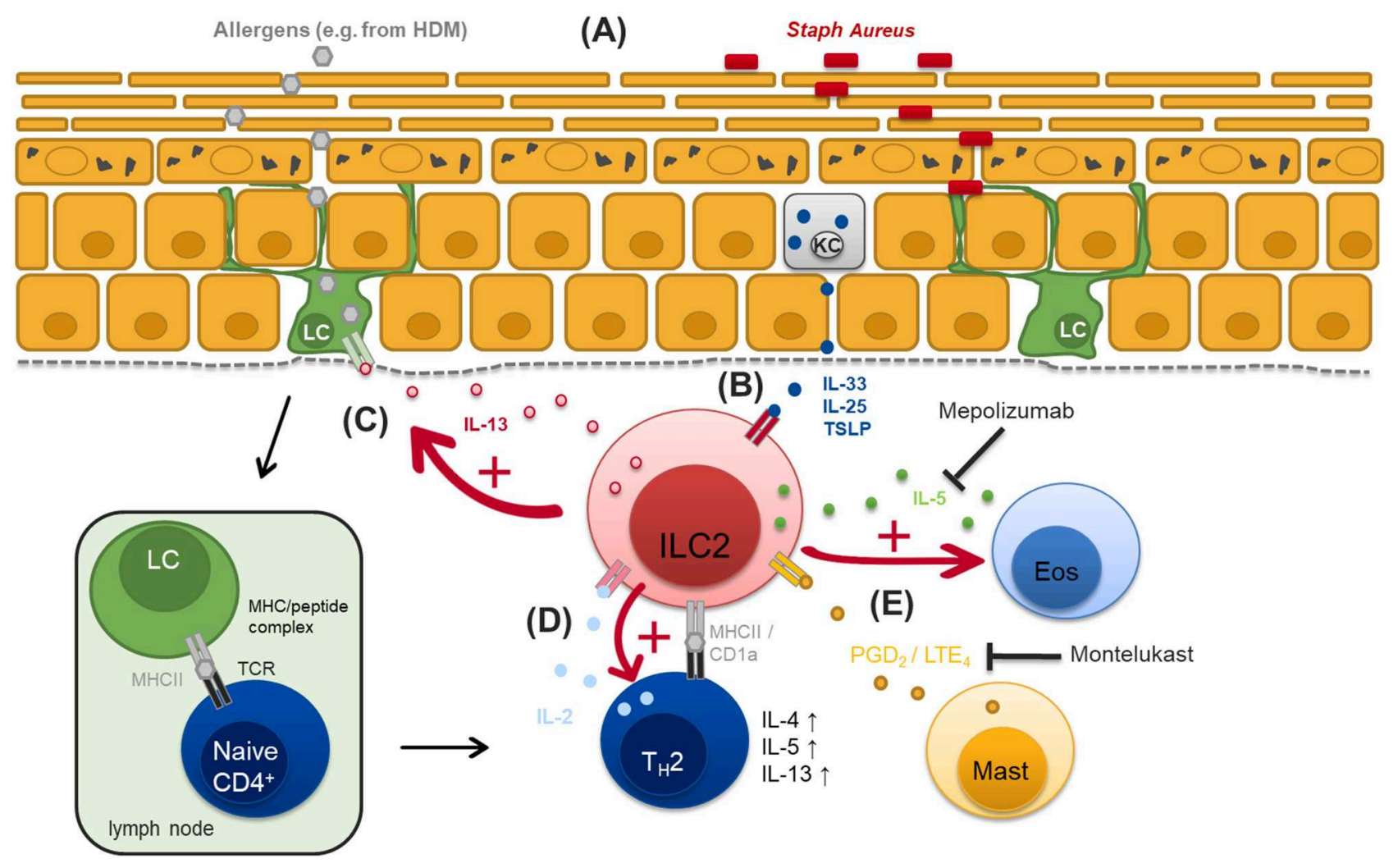

FIGURE 2 | Suggested pathogenic role of ILC2 in atopic dermatitis. (A) Loss-of-function-mutations in the gene coding for the epidermal structure protein filaggrin allow elevated transepidermal water loss (TEWL), higher prevalence of Staphylococcus aureus (Staph Aureus) on the skin and facilitated penetration of allergens, e.g., from house dust mite (HDM). (B) Damaged keratinocytes (KC) release cytokines like interleukin-33 (IL-33), IL-25, and thymic stromal lymphopoietin (TSLP) which activate dermal ILC2. (C) Activated ILC2 produce high amounts of IL-13 which stimulates epidermal Langerhans cells (LC). LC migrate to regional lymph nodes to prime naïve T cells by antigen presentation via MHCII to promote development of $\mathrm{T}_{\mathrm{H}} 2$ cells that produce type II cytokines like IL-4, IL-5, and IL-13. (D) ILC2 can act as antigen presenting cells for $\mathrm{T}_{\mathrm{H}} 2$ effector cells through antigen presentation via MHCII and/or CD1a prompting them to produce IL-2 which in turn sustains ILC2 activation and survival. (E) ILC2 can be activated by mast cell (Mast) derived prostaglandin $\mathrm{D}_{2}\left(\mathrm{PGD}_{2}\right)$ and cysteinyl leukotrienes LTE 4 . ILC2 in turn produce IL-5 which promotes eosinophil (Eos) activation. Administration of montelukast can block LTE 4 -mediated activation of ILC2. IL-5 function can be therapeutically blocked by specific monoclonal antibodies like mepolizumab. MHCIl, major histocompatibility complex II; TCR, T cell receptor.

and upregulation of IL-33/IL-25 receptors in human ILC2 in vitro, but also enhances the pro-inflammatory effect of the epithelial cytokines IL-25, IL-33, TSLP, and of PGD2 as seen by increased production of IL-5 and IL-13. This effect of $\mathrm{LTE}_{4}$ can be partially inhibited by adding the leukotriene antagonist montelukast. Finally, addition of IL-2 to $\mathrm{LTE}_{4}$ and epithelial cytokines significantly further amplifies the activation of ILC2 (67). These findings clearly suggest a pathogenic role of ILC2 in the pathogenesis if atopic dermatitis in humans (Figure 2).

\section{ILC in Atopic Dermatitis Mouse Models}

Topical application of a synthetic form of active vitamin D3 (MC903) to the skin of mice can mimic atopic dermatitislike inflammation with a type 2 signature (68). Using the MC903 AD mouse model Salimi et al. and Kim et al. investigated inflammatory responses in the presence and absence of ILC2. When ILC2 are depleted in $\mathrm{Rag} 1^{-/-}$mice by administering an anti-CD90.2 and/or anti-CD25 monoclonal antibody this leads to an dramatically decreased ear swelling response $(25,36)$. Furthermore, using Ror $\alpha^{\text {sg }} / \mathrm{sg}$ (Ror $\alpha$-knockout) bone marrow chimeric mice which lack ILC2, a markedly reduced inflammatory response in the skin can be seen, highlighting ILC2 as a main proinflammatory cell in this type 2 inflammatory model (36). An increase in IL-33 and IL25 expression has been reported in lesional skin of patients with $\mathrm{AD}$ compared with healthy individuals underlining an important role for these cytokines as proinflammatory ILC2 activating cytokines in $\mathrm{AD}(36,69,70)$. Strikingly, when flow cytometry assisted cell sorting (FACS)-purified ILC2 from MC903-treated C57BL/6 wild-type mice are adoptively transferred by intradermal injection into naïve C57BL/6 wildtype recipient mice, the recipient mice develop $\mathrm{AD}$-like skin reactions with a type $2 \mathrm{~T}$ cell response indicating that these innate cells alone are capable of eliciting an AD-like skin response (25). 


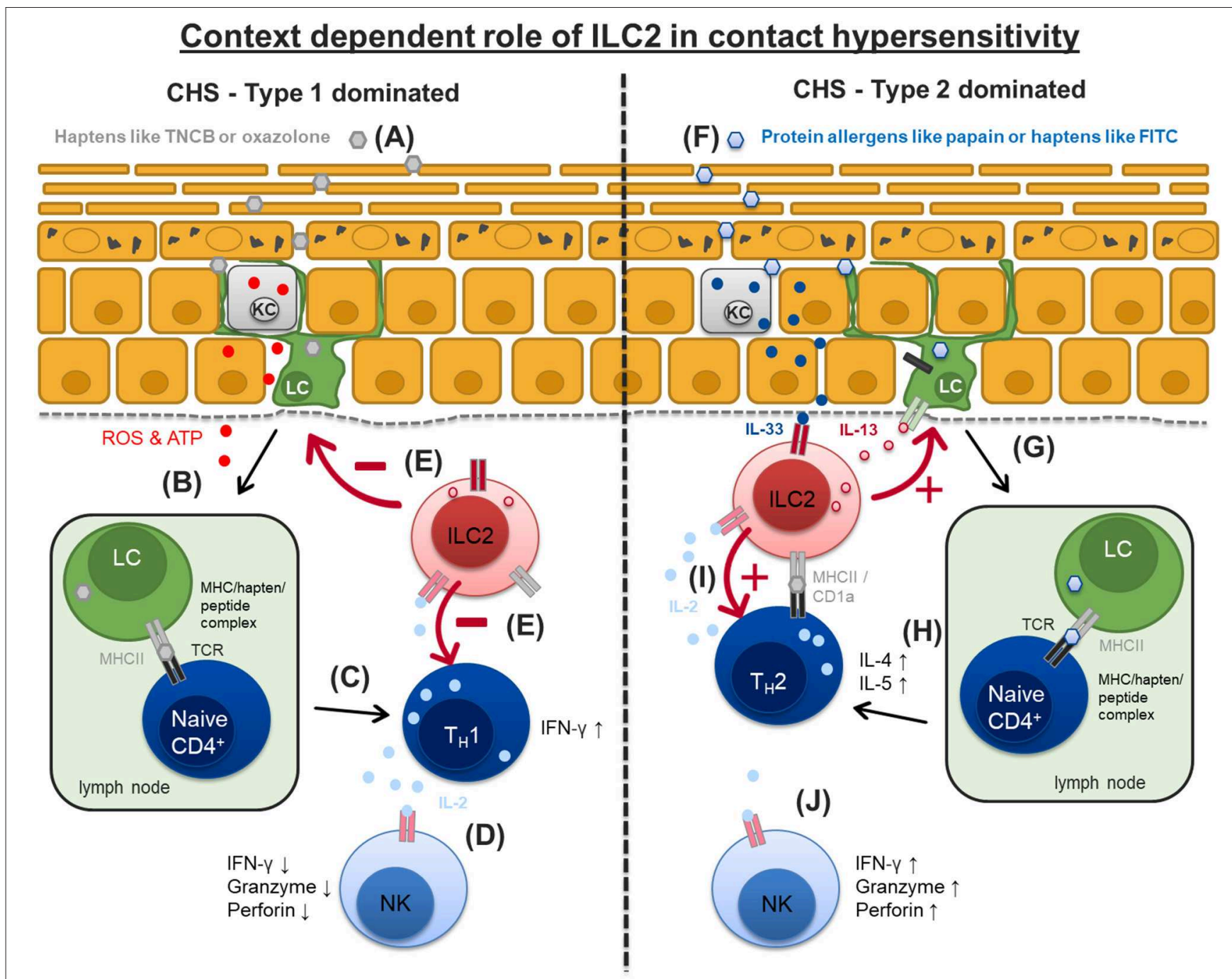

FIGURE 3 | Context dependent role of ILC2 in type 1 and type 2 dominated contact hypersensitivity. Contact allergens irritate and penetrate the upper skin layers. (A) Typical contact allergens like TNCB or oxazololone cause ROS and ATP release from damaged keratinocytes (KC) and uptake by epidermal Langerhans cells (LC). (B,C) LC migrate to skin draining lymph nodes and promote a type 1 driven immune response mediated by $T_{H} 1$ and NK cells resulting in increased IFN- $\gamma$ and IL-2 production. (D) Higher availability of IL-2 for NK cells results in their enhanced activation and effector cytokine production (IFN- $\gamma$, granzyme, perforin). (E) ILC2 are likely to suppress $L C$ migration, $T_{H} 1$ polarization and NK cells activation in this type $1 \mathrm{CHS}$ response via mechanisms that are currently not well-understood. (F) Protein allergens like papain or haptens like FITC cause IL-33 release from keratinocytes (KC) which in turn activates dermal ILC2 to produce large amounts of IL-13. (G,H) ILC2 derived IL-13 promotes trafficking of Langerhans cells (LC) to regional lymph nodes where they prime naïve T cells by interaction of MHCII/peptide/hapten complex and T cell receptor promoting the development of $T_{H} 2$ cells and a type 2 biased immune response. (I) ILC2 can act as antigen presenting cells for $T_{H} 2$ effector cells prompting them to produce IL-2 which in turn sustains ILC2 activation and survival. (J) ILC2 compete with other innate effector cells like NK cells for the survival factor IL-2 leading to a reduced/moderate NK cell activation. FITC, Fluorescein isothiocyanate; MHCII, major histocompatibility complex II; ROS, reactive oxygen species; TCR, T cell receptor; NK, natural killer cell; ATP, Adenosine triphosphate.

Another possible mouse model to study eczema like skin reactions are the "flaky tail" mice. These mice bear a frameshift mutation in the murine filaggrin gene (flg) resulting in expression of a truncated profilaggrin $(\sim 215$ $\mathrm{kDa}$ ) instead of the normal high-molecular-weight profilaggrin $(>500 \mathrm{kDa})(71)$. Topical application of allergen to mice homozygous for this mutation results in cutaneous inflammatory infiltrates and enhanced cutaneous allergen priming with increased development of allergen-specific antibody responses
(71). Saunders et al. characterized changes of ILC2 numbers and their cytokine production in flg-mutant mice (72). These mice show spontaneous atopic dermatitis-like inflammation and develop compromised pulmonary function. In the skin and skin draining lymph nodes of these mice, there is a significant increase in the frequency of IL-5-producing ILC compared to wild type animals. However, no differences in cell numbers are seen for ILC1 and 3. Furthermore, flgmutant mice show higher skin infiltrates of eosinophils, mast 
cells and basophils (72). Even more astonishing, when flgmutant mice are crossed with $\operatorname{Rag} 1^{-/}$mice $\left(\mathrm{Flg}^{\mathrm{ft} / \mathrm{ft}} \operatorname{Rag} 1^{-/-}\right)$ skin lesions but not lung inflammation occur as shown by cutaneous expansion of IL-5-producing ILC2, indicating that skin inflammation can develop independently of the adaptive immune system in these mice (72). Regulation of ILC responses by adaptive immune cells is also reported in other tissues (73). Finally, increased frequency of ILC2 can be found in skin blisters taken from non-lesional skin of patients with filagrin mutations compared with the skin of filagrin wildtype subjects (72). Taken together, loss of filagrin function in humans and mice is clearly linked to increased ILC2 activation and disease progression in atopic dermatitis.

This latter model, however, has been challenged recently by the work of Schwartz et al. which provides evidence that atopic dermatitis like lesions can evolve independent of ILC2 and ILC2derived cytokines in Filaggrin-mutant $\left(\mathrm{Flg}^{\mathrm{ft} / \mathrm{ft}}\right)$ mice bred on an ILC2-deficient background (74). Interestingly, inflammation in these mice following MC903 treatment requires IL-1 $\beta$ and IL-1R1-signaling but is independent of NOD-, LRR- and pyrin domain-containing protein 3 (NLRP3) inflammasome activation and results in elevated numbers of IL-1 $\beta$-responsive connective tissue mast cells (74). Finally, $\mathrm{Flg}^{\mathrm{ft} / \mathrm{ft}}$ mice do not develop skin inflammation under germ-free compared to SPF conditions indicting a crucial role for the microbiome in promoting proinflammatory immune responses in this mouse model (74). This issue will be discussed in more detail in a later section.

\section{ILC2 as Possible Therapeutic Targets in AD}

Development of ILC2 depends on the transcription factor receptor-related orphan receptors alpha $(\operatorname{ROR} \alpha)$ and lack of $R O R \alpha$ results in impaired lung inflammation in response to protease allergen in mice despite normal $\mathrm{T}_{\mathrm{H}} 2$ cell responses (75). Dai et al. provide evidence that a synthetic $\mathrm{ROR} \alpha / \gamma$ inverse agonist (SR1001) is able to suppress inflammation in the MC903induced atopic dermatitis mouse models. Topical treatment with SR1001 reduces epidermal and dermal inflammation, suppresses the production of type 2 cytokines and TSLP, and reverses impaired keratinocyte differentiation (76). Since SR1001 also inhibits ROR $\gamma$ signaling it is quite possible that ROR $\gamma \mathrm{t}^{+}$ILC3 functions may also be impaired (42). If topical inverse agonists for $\operatorname{ROR} \alpha$ may have anti-inflammatory functions in humans remains to be elucidated.

A crucial role for the IL-33/ILC2 axis in the pathogenesis of $\mathrm{AD}$ has been proposed by Imai et al. The authors generated a transgenic mouse line which overexpresses IL33 in keratinocytes. These mice spontaneously develop an itchy dermatitis closely resembling $\mathrm{AD}$ at age 6-8 weeks with thickened epidermis, skin infiltration of eosinophils and mast cells, and high histamine and IgE levels in the blood (77). Moreover, IL-5 and IL-13 expressing ILC2 numbers are significantly increased in lesional skin, peripheral blood, and regional lymph nodes. Administering a neutralizing monoclonal anti-IL-5 antibody results in a marked reduction of the inflammatory response as shown by a decreased peripheral blood eosinophil count, milder thickened epidermis and lower inflammatory infiltrates including eosinophils (77).
Unfortunately, a randomized, placebo-controlled parallel group design study in patients with $\mathrm{AD}$ could not detect a clinical improvement by administering a monoclonal antibody to human interleukin-5 (mepolizumab) in two single doses of $750 \mathrm{mg}$, given 1 week apart, despite a significant decrease in peripheral blood eosinophils (78).

\section{ROLE OF ILC IN ALLERGIC CONTACT DERMATITIS}

Allergic contact dermatitis (ACD) is a prevalent inflammatory skin disease triggered by low molecular weight organic chemicals or metal ions which penetrate the skin and bind covalently or by complex formation to proteins thereby activating the innate and adaptive immune response. ACD can be separated into two phases. The sensitization phase, were antigen upon first encounter with the skin is taken up by dendritic cells and transferred to the regional draining lymph nodes to be presented to antigen specific T-cells for priming. And the elicitation phase that is induced by subsequent antigen contact and leads to an infiltration of antigen-specific T-cells into the skin peaking $24-48 \mathrm{~h}$ after second antigen contact. In the mouse model of ACD, the contact hypersensitivity (CHS) model, hapten-specific $\mathrm{CD}^{+}$cytotoxic T-cells are thought to be the key effector cells in the elicitation phase rendering CHS a classical type 1 driven adaptive immune response (Figure 3). Typical haptens used in these models comprise oxazolone, 2,4,6-Trinitrochlorobenzene (TNCB) or 2,4-dinitrofluorobenzene (DNFB) (79-81). In addition, we and others have previously demonstrated that sensing of danger signals by cells of the innate immune system including dendritic cells, neutrophils, and mast cells represent a crucial element in the initiation and elicitation of CHS responses (82-86).

\section{NK Cells in Type 1 Dominated CHS Responses}

Group 1 ILCs consisting of NK cells and ILC1 are involved in inflammatory bowel and allergic skin diseases in mice (12, 24, 87, 88). Regarding ACD Carbone et al. were able to characterize CD56 ${ }^{\text {high }} \mathrm{CD} 16^{-} \mathrm{CD}^{-} \mathrm{L}^{-} \mathrm{NK}$ cells in an ex vivo human model which accumulate in affected skin of hapten allergic human individuals and these NK cells release type 1 cytokines and induce keratinocyte apoptosis in vitro (23). In mice NK cells can be further subdivided into two distinct subsets: CD49a ${ }^{+} \mathrm{DX} 5^{-}$ liver-resident $\left(\right.$ Trail $^{+}$) and CD49a ${ }^{-} \mathrm{DX}^{+}$conventional NK cells (cNK) (12). Furthermore, cNK cells seem to express much higher amounts of the transcription factor EOMES (87). Liver-resident NK cells can mediate long-lived, antigen-specific adaptive recall responses to haptens like DNFB and oxazolone independent of B cells and T cells (24). Preceding was the finding that a CHS response to several haptens can be elicited in Rag2-/mice lacking $\mathrm{T}$ - and $\mathrm{B}$-cells but not in mice that either contain dysfunctional NK cells (SCID $\times$ beige mice) or completely lack NK cells (Rag2 $-/-$ Il2 $\mathrm{rg}^{-/-}$mice). A proper CHS response can be transferred by FACS-purified antigen-specific Thy-1 ${ }^{+}$ Ly49C-I ${ }^{+}$liver-resident NK cells from sensitized Rag2 $2^{-/-}$mice 
when transferred into naive $\mathrm{Rag}^{-/-} \mathrm{Il}_{\mathrm{rg}}{ }^{-/-}$recipients (24). The same NK cell type seems to mount antigen specific immunity against certain viral pathogens as well (88). Our own investigations using the hapten TNCB support the role of EOMES $^{+}$cNK cells as the dominant proinflammatory innate cell type in the early phase of contact hypersensitivity. NK cell numbers increase significantly $24 \mathrm{~h}$ in the ear skin of mice after allergen challenge and produce type 1 marker cytokines like IFN- $\gamma$ and TNF (89). Taken together, NK cells seem to represent a major driving force of the innate immune system in CHS pathogenesis pathogenesis (Figures 3A-D).

\section{Helper-Like ILC in Type 1 Dominated CHS Responses}

Very little is known about the involvement of helper-like ILC in the pathogenesis of CHS, however there has been some indirect evidence for it in the past. ILC2 are known to be a major source of IL-13 production thus playing a crucial role in innate type 2 immune responses to worms and inhaled allergens $(90,91)$. IL-13-deficient mice (Il13 ${ }^{-/}$) show impaired $\mathrm{T}_{\mathrm{H}} 2$ responses induced by epicutaneous ovalbumin (OVA) exposure whereas i.p. sensitization is normal and results in responses equivalent to wild type mice (92). Interestingly, $1113^{-/-}$mice display an even enhanced ear swelling responses to the hapten DNFB, which is also known to elicit a type 1 T-cell driven immune response (93), compared to wild type mice. At the time, this finding was interpreted as a lack of $\mathrm{T}_{\mathrm{H}} 2$-mediated suppression but it's tempting to speculate that impaired ILC2 function in this mouse model may also have contributed to a disinhibited and thus exaggerated type 1 immune response. We recently characterized cell numbers and cytokine production of all ILC subgroups (ILC1-3 and NK cells) during the elicitation phase of a CHS mouse model based on the hapten TNCB using an ILC reporter system (89). Numbers of ILC are elevated in skin draining lymph nodes, show an activated phenotype and produce elevated amounts of their marker cytokines IL-13 and IL-5 at late time points ( 48 and $72 \mathrm{~h}$ ), i.e., during the resolution phase of the inflammatory response in the skin. On the other hand, NK cell numbers and their production of IFN- $\gamma$ and TNF are highest $24 \mathrm{~h}$ after allergen challenge paralleling the strongest skin inflammation period (89). The latter is expected since TNCB is known to elicit a type 1 driven immune response $(93,94)$. However, lack of ILC achieved by either antibody mediated depletion using an anti CD $90.2 \mathrm{mAb}$ in Rag1 $1^{-/-}$mice or by using mice that selectively lack ILC2 [Ror $\alpha^{\mathrm{sg} / \text { flox }} \mathrm{Il} \mathrm{r}^{\mathrm{Cre} /+}$ mice (29)] results in a significantly enhanced and long lasting inflammatory response (89). The ear infiltrate of ILC depleted mice show a tendency toward a more type 1 biased immune response indicated by increased numbers of T-bet ${ }^{+} \mathrm{CD}^{+}$T-cells (89). This data supports the concept of a counter regulatory role for ILC2 in CHS (Figures 3A-D).

\section{Helper-Like ILC in Type 2 Dominated Allergic Skin Responses}

Some allergens like Fluorescein isothiocyanate (FITC) and papain rather induce allergic type 2 immune responses with increased IL-4 producing $\mathrm{T}_{\mathrm{H}} 2$ cell infiltrates in murine skin when reapplied topically or intradermally $(28,95,96)$, suggesting that
ILC2 might rather play a proinflammatory role in these models. Along this line we demonstrated in a papain skin challenge model that lack of IL-13-producing ILC2 leads to a marked reduction of inflammation with less skin infiltrating $\mathrm{T}_{\mathrm{H}} 2$ cells [(28); (Figures 3F-J)]. A first therapeutic approach in type 2 dominated allergic skin responses has been proposed by Bao et al. They demonstrate that ILC2 numbers are increased in the skin of FITC-challenged mice. In addition, intraperitoneal injection of the cycloartane triterpene saponin Astragaloside IV during the sensitization phase leads to a reduction of the inflammatory response as seen by a decreased ear swelling response, less production of pro-allergic cytokines like IL33 and TSLP, and significantly reduced numbers of ILC2 in the skin of these mice (97). Thus, ILC2 seem to have contrary roles in type 1 and type 2 dominated allergic skin reactions, respectively (Figure 3).

\section{ROLE OF DERMAL ILC2 IN INNATE AND ADAPTIVE IMMUNE CROSS TALK}

\section{Antigen Presentation by MHCII}

ILC2 and ILC3 express MHCII molecules on their surface and can act as antigen presenting cells for helper $\mathrm{T}$ cells $(29,51,52)$. Our own analysis of MHCII expression on ILC2 revealed that in skin draining lymph nodes of mice $\sim 50 \%$ of the ILC2 express MHCII, while in the skin only 3\% express MHCII. Antibody mediated depletion of ILC leads to a significant reduction of MHCII positive ILC2 both in skin and LN (89). Currently, we can only speculate that ILC2 might regulate effector T cells in a direct fashion via MHCII. In line with this, Oliphant et al. recently demonstrated that MHCII expression on ILC2 and subsequent antigen presentation to $\mathrm{CD} 4^{+} \mathrm{T}$ cells is crucial for successful helminth expulsion in mice (29). The crosstalk between ILC2 and CD4 ${ }^{+} \mathrm{T}$ cells seems to involve IL-2 since activated $\mathrm{CD} 4^{+} \mathrm{T}$ cell-derived IL-2 has been shown to synergize with IL-33 to stimulate ILC2 (29). Thus, lack of ILC2 may lead to a higher availability of IL-2 for proliferation of other effector cells like NK cells leading to an augmented response in CHS.

\section{Antigen Presentation by CD1a}

Another way how ILC2 might crosslink innate and adaptive immunity is by expressing the lipid-presenting molecule CD1a. Other than classical MHC proteins that present peptides, CD1 molecules present endogenous and exogenous lipid antigens to T lymphocytes (98). In a CHS model using the poison ivy-derived lipid contact allergen urushiol, CD1a expressing Langerhans cells are important to promote CDla-restricted $\mathrm{CD}^{+} \mathrm{T}$ cells to produce IL-17 and IL-22. Furthermore, treatment with blocking antibodies against $\mathrm{CD} 1 \mathrm{a}$ alleviates skin inflammation dramatically (99). More recently Hardman et al. demonstrated in a human skin challenge model that skin-derived ILC2 not only express CD1a but are also capable of helping CD1a-reactive $\mathrm{T}$ cells to sense $S$. aureus components in an cytosolic phospholipase A2 (PLA2G4A) and TLR-dependentdependent manner, suggesting a new role for ILC2 in lipid surveillance of the skin (100). Currently, it is unclear whether this also applies for the adaptive immune response against 
urushiol. Taken together CD1a expression on ILC2 seems to be clearly involved in shaping the phenotype of adaptive $\mathrm{T}$ cell responses.

\section{Crosstalk With Basophils and Macrophages}

Mashiko et al. reported significantly elevated frequencies of basophils, ILC and $\mathrm{T}_{\mathrm{H}} 2$ cells in the lesional skin of $\mathrm{AD}$ patients compared to patients suffering from psoriasis. Interestingly, basophils and ILC2 are positively correlated in skin, whereas skin basophils are inversely correlated with blood ILC2 suggesting that skin basophils may attract circulating ILC2 to skin of AD patients by IL-4 production (101). Kim et al. detected elevated numbers of basophils and ILC that form clusters in inflamed human $\mathrm{AD}$ skin compared to control skin. Using the MC903-based AD mouse model in IL4/GFP reporter mice, they demonstrated that murine basophil responses preceded ILC2 responses and those basophils are the dominant IL-4-producing cell type in inflamed skin. In addition, ILC2 express the IL-4 receptor IL-4R $\alpha$ and proliferate in an IL-4-dependent manner. Finally using $\mathrm{Il}^{-/-}$mice Kim et al. provide evidence that especially basophil-derived IL4 is necessary for proinflammatory ILC2 responses in the skin (102).

Most notably, Egawa et al. have shown that basophil-derived IL-4 converts $\mathrm{Ly} 6 \mathrm{C}^{+} \mathrm{CCR} 2^{+}$inflammatory monocytes into antiinflammatory M2 macrophages in an IgE-mediated chronic allergic inflammation (IgE-CAI) mouse model, a model where basophils rather than mast cells and $\mathrm{T}$ cells play a critical role for the elicitation of allergic response $(103,104)$. In this model, skin infiltrating monocytes acquire an M2-like phenotype in an IL-4R- and basophil-dependent manner and adoptive transfer of $\mathrm{Ly}_{6} \mathrm{C}^{+} \mathrm{CCR} 2^{+}$inflammatory monocytes dampens the exacerbated IgE-CAI in CCR2 $2^{-/-}$mice which also requires IL-4R signaling (103). Thus, it is tempting to speculate, that basophil-derived IL-4 may promote pro-inflammatory responses via ILC2 and anti-inflammatory signals via M2 macrophages at the same time, leading to a counterbalanced immune response. However, the role of ILC2 in the IgE-CAI model is not known so far.

On the other side, ILC2 have been shown to promote polarization of the anti-inflammatory M2 macrophages by producing type- 2 cytokines (IL-4, IL-5, and IL-13) in an renal ischemia-reperfusion injury model and experimental cerebral malaria $(105,106)$. Furthermore, in obese mice PD- ${ }^{\text {high }}$ ILC2 are inhibited by PD-L1 expressing M1 macrophages which is promoted by TNF. PD-1 blockade improves ILC2 function, reinforces type 2 innate responses and promotes adipose tissue homeostasis $(107,108)$. Interestingly, in an seruminduced arthritis mouse model ILC2 were indispensable for dampening proinflammatory IL-1 $\beta$ secretion by bone marrowderived macrophages (109). Finally, basophil-derived IL-4 seems to be essential for M2 macrophage mediated trapping of Nippostrongylus Brasiliensis larvae in the skin during second infection of mice thereby leading to reduced worm burden in the lung (110). However, basophils had no apparent contribution to worm expulsion from the intestine highlighting their crucial role in the skin (110).

Taken together, there seems to be an intense crosstalk between basophils, ILC2 and macrophages involving cytokines like IL4 , IL-13, and IL1 $\beta$ and resulting in differential polarization of macrophages dependent on the disease model. How these three cell type interact in $\mathrm{AD}$ and $\mathrm{CHS}$ remains to be elucidated.

\section{Crosstalk With Dendritic Cells}

Using the protease-allergen papain which induces type 2 allergic airway and skin inflammation we showed that ILC2 are necessary for mounting an appropriate antigen specific $\mathrm{T}_{\mathrm{H}} 2$ memory response and that ILC2 activation clearly precedes $\mathrm{T}_{\mathrm{H}} 2$ involvement in papain induced airway and skin inflammation (28). Furthermore, ILC2-derived IL-13 is needed for the activation and expansion of an allergen-induced subset of dendritic cells $\left(\mathrm{CD} 11 \mathrm{~b}^{+} \mathrm{CD} 103^{-} \mathrm{IRF}^{+}\right)$which produce the $\mathrm{T}_{\mathrm{H}} 2$ cell chemoattractant CCL17. Using ILC2-deficient mice, we demonstrated that dermal ILC2 are crucial to mediate expansion of $\mathrm{CCL}_{1} 7^{+}$dendritic cells after skin challenge with papain finally leading to an effective $\mathrm{T}_{\mathrm{H}} 2$ memory response. Thus, ILC2 licensing of dendritic cells is a critical component of the memory $\mathrm{T}_{\mathrm{H}} 2$ cell response to certain allergens at barrier sites (28).

\section{INFLUENCE OF SKIN MICROBIOTA ON ILC2 IMMUNITY}

As mentioned earlier, filaggrin mutant mice significantly differ in their microbiome composition compared to wild type mice and do not develop skin inflammation under germ-free conditions prompting a crucial role for the microbiome in shaping this setting (74). Several studies have investigated the role of skin commensal bacteria in shaping the host immune cell functions of this organ (111-113). This mostly involves skin derived dendritic cells as sensors of bacterial antigens which promote development of commensal-specific $\mathrm{T}$ cells. These $\mathrm{T}$ cells help to improve tissue repair and protection to pathogens rendering them as important players in the skin homeostasis $(111,112)$.

When analyzing different skin-derived bacterial strains in a pediatric $\mathrm{AD}$ cohort over time, Byrd et al. were able to detect certain clonal $S$. aureus strains which are associated with more severe disease (113). Interestingly, heterogeneous Staphylococcus epidermidis strains were found in patients with less severe disease indicating that clonal expansion of certain bacterial strains can trigger proinflammatory responses in human $\mathrm{AD}$. Furthermore, S. aureus isolates from $\mathrm{AD}$ patients with more severe flares can induce epidermal thickening and expansion of cutaneous $\mathrm{T}_{\mathrm{H}} 2$ and $\mathrm{T}_{\mathrm{H}} 17$ cells in a murine AD model (113).

These findings are suggesting a role of the microbiome to shape ILC2 functions as well. Interestingly, ILC2 distribution and homeostatic function in bone marrow, fat, lung, gut, and skin seems to be independent of commensal microbiota when comparing SPF to germ free mice (114). However, in mouse model of chronic obstructive pulmonary disease (COPD), challenge with S. aureus or Haemophilis influenzae lead to loss of GATA-3 expression in ILC2 and a subsequent increase in the 
expression of IL-12R $\beta 2$, IL-18R $\alpha$, and T-bet giving them an ILC1like phenotype (115). This ILC2 plasticity can also be influenced by viral stimuli especially influenza A virus (115).

Taken together, there is substantial evidence that the microbiome is involved in shaping ILC2 function and plasticity, especially in inflammatory lung diseases. Whether this concept also applies to the pathogenesis of inflammatory skin disease like $\mathrm{AD}$ and $\mathrm{CHS}$ remains to be determined.

\section{TYPE 1 AND TYPE 2 COUNTER REGULATION IN CHS}

Type 1 and type 2 immune responses are known to tightly counter-regulate each other (116). $\mathrm{T}_{\mathrm{H}} 1$ cytokines such as IFN$\gamma$ have been shown to antagonize the function of ILC2 and type 2 innate immune responses in mouse models of allergic lung inflammation and viral respiratory tract infections (13, 117). ILC2-mediated lung inflammation is enhanced in the absence of the IFN- $\gamma$ receptor on ILC2 cells in vivo and IFN- $\gamma$ effectively suppresses the function of tissue-resident ILC2 cells, two observations that clearly suggest a suppressive function of type 1 cytokines on ILC2 (13). Our own investigations reveal that TNCB based CHS in a mouse model is counter regulated by activated ILC, since lack of all ILC or ILC2 alone leads to a dramatic increase in the inflammatory response with a type 1 immune response bias (89). More recently, it has been reported that in the early stage of papain-induced lung inflammation in mice, depletion of NK cells results in increased numbers and cytokine production of ILC2, suggesting that NK cells negatively regulate ILC2 (118). Hapten based CHS experiments in Il15 ${ }^{-/-}$ mice, which lack NK cells, demonstrate dramatically reduced ear swelling responses and at the same time increased numbers of ILC2 in skin and skin draining lymph nodes (89). Thus, a mutual balance between type 1 and type 2 immunity may also exist in CHS, in which NK cells negatively regulate ILC2 and ILC2 counter regulate type 1 immune responses mainly driven by NK cells, $\mathrm{T}_{\mathrm{H}} 1$, and $\mathrm{T}_{\mathrm{C}} 1$ cells.

Recently, Kim et al. identified IL-10-producing lineage negative lymphoid cells that show elevated numbers in the axillary as well as inguinal lymph nodes and ear tissues of Oxazolone challenged mice suggesting a possible regulatory role of ILC (119). These cells were designated "ILC10" and identified by expression of markers like CD45, CD127, and Sca-1, while detailed characterization of the exact ILC subpopulation was not provided. Along the same line, an IL-10 producing ILC2 effector cell population has recently been described in murine lung and suggested to regulate immune responses in a papain induced allergic lung inflammation model (4). These studies prompted us to address the presence of IL-10 producing ILC. Using highly sensitive IL-10 transcriptional reporter mice (120) we, however, could not identify relevant numbers of IL-10 transcribing lineage negative cells in different tissues (skin, lymph nodes, blood, and spleen) in the TNCB induced CHS model (89). Thus, at least in our hands ILC derived IL-10 does not appear to be responsible for the regulatory effects of ILC in type 1 dominated CHS of the skin.
Nevertheless, ILC2 are reported to promote regulatory T (Treg) cell expansion, thus framing the hypothesis that ILC2 can regulate inflammation indirectly. Molofski et al. demonstrated that ICOSL expression by ILC2 can stimulate ICOS ${ }^{+}$Treg cells, providing a potential indirect link between IL-33 and Treg cells (121). In line with this, Rauber et al. could demonstrate that IL-9 producing ILC2 are crucial in promoting Treg driven anti-inflammatory effects in an antigen-induced arthritis mouse model. This ILC2/Treg interaction was dependent on direct cell contact involving ICOS-ICOSL interaction (122).

We recently showed that IL-33-induced OX40L expression by ILC2 is critical for tissue-specific expansion of Treg cells (32). Moreover, our data indicates that OX40L/OX40driven interactions between ILC2 and Treg cells preferentially expands GATA3 $^{+}$Treg cells, which are thought to be tissue-resident and functionally primed (123). IL-33-induced OX40L expression by ILC2 and the associated Treg cell expansion seems to be restricted to specific anatomical locations such as the airway and adipose tissue but not LN or gut (32). Thus, it remains unknown if a similar mechanism or alternative ILC2-independent suppressive pathways are involved in the skin.

Malhotra et al. recently found skin resident ROR $\alpha$-expressing Tregs to dampen ILC2-driven inflammation in a mouse model for atopic dermatitis (124). This effect is thought to be based on the enhanced expression of TNF ligandrelated molecule 1 (TL1A) and death receptor 3 (DR3) on ILC2 as well as suppressed IL-4 expression. ROR $\alpha$ expressing Tregs are found in higher numbers in human skin compared to peripheral blood suggesting a possible counter regulatory role for these cells in ILC2-driven allergic skin diseases (124).

Taken together, these data show that ILC2 can act as modulators of the adaptive immune response and that the functional outcome very much depends on the context of the inflammatory reaction that is analyzed. In type 2 dominated skin inflammation ILC2 seem to be primarily proinflammatory while in the context of a type 1 dominated immune response ILC2 can act as regulators that help to counterbalance the inflammatory reaction (Figure 3).

\section{CONCLUDING REMARKS AND OUTLOOK}

Innate lymphoid cells are increasingly emerging as important effectors of the innate immune system finally shaping a distinctive adaptive immune response. This includes on the one side important physiological functions in promoting wound healing, adipose tissue homeostasis, protection from pathogens and dampening of certain inflammatory disorders via Treg induction. On the other side, ILC2 have been shown to be important proinflammatory players in diseases like allergic asthma and atopic dermatitis. In the case of atopic dermatitis ILC2 have been described to be the major proinflammatory ILC subtype accountable for the production of marker cytokines like IL-13 and IL-5, cross-talk with other innate cells like basophils and dendritic cells, and finally promoting the development of 
$\mathrm{T}_{\mathrm{H}} 2$ cells. ILC2 will continue to be of high interest as possible targets in $\mathrm{AD}$ therapy, especially concerning their potential to produce high amounts of cytokines.

Immunologic reaction in allergic contact dermatitis can differ depending on the type of hapten used. Haptens like TNCB or oxazolone inducing type 1 responses clearly favor NK cells and $\mathrm{T}_{\mathrm{H}} 1$ cells as the driving proinflammatory force. In these models ILC2 may have counter regulatory functions as our own investigations suggest. On the other side, in allergic type 2 responses of the skin, induced by distinct haptens like FITC or protein allergens like papain, ILC2 seem to have a proinflammatory role. These observations clearly emphasize a context dependent function of ILC2 which is determined by the type of model analyzed (type 1 or type 2 dominated).

Additionally, ILC2 have recently been shown to be part of a neuro-immune interface. ILC2 function can be influenced by the neuropeptide neuromedin $\mathrm{U}$ (NMU) secreted by cholinergic neurons in the mucosal tissue of the gut and lungs. This goes in line with other studies showing that further neuroendocrine factors like norepinephrine, vasoactive intestinal peptide (VIP), calcitonin gene-related peptide (CGRP), and acetylcholine can modify ILC2 function as well (125-131). Furthermore, challenge of mouse skin with the poison ivy compound urushiol leads to an increase in IL-33 expression which can act on small to mediumsized dorsal root ganglion neurons that innervate the skin and express the IL-33 receptor ST2 (132). Strikingly, targeting IL33 by either neutralizing antibodies or intrathecal application of ST2 siRNA results in significantly reduced itching and subsequently less scratching behavior in these mice, suggesting a new therapeutic approach in poison ivy ACD (132). Since pruritus is a hallmark symptom of $\mathrm{ACD}$ in humans and mice which is mediated by certain sensory neurons (133) it

\section{REFERENCES}

1. Constantinides MG, McDonald BD, Verhoef PA, Bendelac A. A committed hemopoietic precursor to innate lymphoid cells. Nature. (2014) 508:397-401. doi: 10.1038/nature13047

2. Eberl G, Colonna M, Santo JPD, McKenzie ANJ. Innate lymphoid cells: a new paradigm in immunology. Science. (2015) 348:aaa6566. doi: 10.1126/science.aaa6566

3. Klose CS, Diefenbach A. Transcription factors controlling innate lymphoid cell fate decisions. Curr Top Microbiol Immunol. (2014) 381:215-55. doi: 10.1007/82_2014_381

4. Seehus CR, Kadavallore A, Torre B de la, Yeckes AR, Wang Y, Tang J, et al. Alternative activation generates IL-10 producing type 2 innate lymphoid cells. Nat Commun. (2017) 8:1900. doi: 10.1038/s41467-01702023-z

5. Crome SQ, Nguyen LT, Lopez-Verges S, Yang SYC, Martin B, Yam JY, et al. A distinct innate lymphoid cell population regulates tumor-associated T cells. Nat Med. (2017) 23:368-75. doi: 10.1038/nm.4278

6. Wang S, Xia P, Chen Y, Qu Y, Xiong Z, Ye B, et al. Regulatory innate lymphoid cells control innate intestinal inflammation. Cell. (2017) 171:201-16.e18. doi: 10.1016/j.cell.2017.07.027

7. Klose CSN, Artis D. Innate lymphoid cells as regulators of immunity, inflammation and tissue homeostasis. Nat Immunol. (2016) 17:765-74. doi: $10.1038 /$ ni.3489

8. Vosshenrich CAJ, García-Ojeda ME, Samson-Villéger SI, Pasqualetto V, Enault L, Goff OR-L, et al. A thymic pathway of mouse natural killer is tempting to speculate that this new identified "neuronILC2 unit" may also be important in the pathogenesis of AD and ACD. This hypothesis is further supported by studies showing that type 2 cytokines like TSLP and IL- 4 can enhance itching $(134,135)$.

Taken together, the picture of ILC function in allergic skin diseases is far from complete. Further investigations especially on the mode of action of how ILC modify immune responses in a context dependent fashion are needed to fill this gap of knowledge.

\section{AUTHOR CONTRIBUTIONS}

DR-S did the main research and wrote the first draft of the manuscript. $\mathrm{CK}, \mathrm{TH}$, and YT provided substantial contributions to acquisition, analysis, and interpretation of the scientific content of this work. TJ provided the main contribution to the conception and design of the work. All authors contributed to manuscript revision, read, and approved the submitted version.

\section{FUNDING}

Research in the lab of YT was funded by the DFG (TA 436/4-1 and P06/SFB1160) and the Else Kröner-Fresenius Stiftung (2017_EKES.34). DR-S was supported by the clinician scientist programme Excellent Clinician Scientists in FreiburgEducation for Leadership (EXCEL) of the Faculty of Medicine, University of Freiburg, funded by the Else Kröner-FreseniusStiftung. This work was supported by grants from the German Research Foundation (DFG; KL 2963/2-1 and SPP1937 - KL 2963/3-1 to CK) and the European Research Council (ERCEA; ERC Starting Grant \#803087 to CK). cell development characterized by expression of GATA-3 and CD127. Nat Immunol. (2006) 7:1217-24. doi: 10.1038/ni1395

9. Veinotte LL, Halim TYF, Takei F. Unique subset of natural killer cells develops from progenitors in lymph node. Blood. (2008) 111:4201-8. doi: 10.1182/blood-2007-04-087577

10. Huang Y, Mao K, Chen X, Sun M, Kawabe T, Li W, et al. S1P-dependent interorgan trafficking of group 2 innate lymphoid cells supports host defense. Science. (2018) 359:114-9. doi: 10.1126/science.aam5809

11. Gasteiger G, Fan X, Dikiy S, Lee SY, Rudensky AY. Tissue residency of innate lymphoid cells in lymphoid and non-lymphoid organs. Science. (2015) 350:981-5. doi: 10.1126/science.aac9593

12. Peng H, Jiang X, Chen Y, Sojka DK, Wei H, Gao X, et al. Liver-resident NK cells confer adaptive immunity in skin-contact inflammation. J Clin Invest. (2013) 123:1444-56. doi: 10.1172/JCI66381

13. Moro K, Kabata H, Tanabe M, Koga S, Takeno N, Mochizuki M, et al. Interferon and IL-27 antagonize the function of group 2 innate lymphoid cells and type 2 innate immune responses. Nat Immunol. (2016) 17:76-86. doi: 10.1038/ni.3309

14. Bando JK, Liang H-E, Locksley RM. Identification and distribution of developing innate lymphoid cells in the fetal mouse intestine. Nat Immunol. (2015) 16:153-60. doi: 10.1038/ni.3057

15. Schuijs MJ, Halim TYF. Group 2 innate lymphocytes at the interface between innate and adaptive immunity. Ann N Y Acad Sci. (2018) 1417:87-103. doi: 10.1111/nyas.13604

16. Klose CSN, Blatz K, d'Hargues Y, Hernandez PP, Kofoed-Nielsen M, Ripka JF, et al. The transcription factor T-bet is induced by IL-15 and 
thymic agonist selection and controls $\mathrm{CD} 8^{\alpha \alpha+}$ intraepithelial lymphocyte development. Immunity. (2014) 41:230-43. doi: 10.1016/j.immuni.2014. 06.018

17. Gordon SM, Chaix J, Rupp LJ, Wu J, Madera S, Sun JC, et al. The transcription factors T-bet and Eomes control key checkpoints of natural killer cell maturation. Immunity. (2012) 36:55-67. doi: 10.1016/j.immuni.2011.11.016

18. Sojka DK, Plougastel-Douglas B, Yang L, Pak-Wittel MA, Artyomov MN, Ivanova Y, et al. Tissue-resident natural killer (NK) cells are cell lineages distinct from thymic and conventional splenic NK cells. eLife. (2014) 3:e1659. doi: 10.7554/eLife.01659

19. Daussy C, Faure F, Mayol K, Viel S, Gasteiger G, Charrier E, et al. Tbet and Eomes instruct the development of two distinct natural killer cell lineages in the liver and in the bone marrow. J Exp Med. (2014) 211:563-77. doi: $10.1084 / \mathrm{jem} .20131560$

20. Abt MC, Lewis BB, Caballero $\mathrm{S}$, Xiong $\mathrm{H}$, Carter RA, Sušac B, et al. Innate immune defenses mediated by two ILC subsets are critical for protection against acute clostridium difficile infection. Cell Host Microbe. (2015) 18:2737. doi: 10.1016/j.chom.2015.06.011

21. Spits H, Bernink JH, Lanier L. NK cells and type 1 innate lymphoid cells: partners in host defense. Nat Immunol. (2016) 17:758-64. doi: $10.1038 /$ ni.3482

22. Fuchs A, Vermi W, Lee JS, Lonardi S, Gilfillan S, Newberry RD, et al. Intraepithelial type 1 innate lymphoid cells are a unique subset of IL-12- and IL-15-responsive IFN-gamma-producing cells. Immunity. (2013) 38:769-81. doi: 10.1016/j.immuni.2013.02.010

23. Carbone T, Nasorri F, Pennino D, Eyerich K, Foerster S, Cifaldi L, et al. $\mathrm{CD} 56^{\text {high }} \mathrm{CD} 16^{-} \mathrm{CD} 62 \mathrm{~L}^{-} \mathrm{NK}$ cells accumulate in allergic contact dermatitis and contribute to the expression of allergic responses. J Immunol. (2010) 184:1102-10. doi: 10.4049/jimmunol.0902518

24. O'Leary JG, Goodarzi M, Drayton DL, von Andrian UH. T cell- and B cell-independent adaptive immunity mediated by natural killer cells. Nat Immunol. (2006) 7:507-16. doi: 10.1038/ni1332

25. Kim BS, Siracusa MC, Saenz SA, Noti M, Monticelli LA, Sonnenberg GF, et al. TSLP elicits IL-33-independent innate lymphoid cell responses to promote skin inflammation. Sci Transl Med. (2013) 5:170ra16. doi: 10.1126/scitranslmed.3005374

26. Rak GD, Osborne LC, Siracusa MC, Kim BS, Wang K, Bayat A, et al. IL-33dependent group 2 innate lymphoid cells promote cutaneous wound healing. J Invest Dermatol. (2015) 136:487-96. doi: 10.1038/JID.2015.406

27. Christianson CA, Goplen NP, Zafar I, Irvin C, Good JT Jr, Rollins DR, et al. Persistence of asthma requires multiple feedback circuits involving type 2 innate lymphoid cells and IL-33. J Allergy Clin Immunol. (2015) 136:59-68.e14. doi: 10.1016/j.jaci.2014.11.037

28. Halim TY, Hwang YY, Scanlon ST, Zaghouani H, Garbi N, Fallon PG, et al. Group 2 innate lymphoid cells license dendritic cells to potentiate memory $\mathrm{T}$ helper 2 cell responses. Nat Immunol. (2016) 17:57-64. doi: 10.1038/ni.3294

29. Oliphant CJ, Hwang YY, Walker JA, Salimi M, Wong SH, Brewer JM, et al. MHCII-mediated dialog between group 2 innate lymphoid cells and $\mathrm{CD} 4^{+} \mathrm{T}$ cells potentiates type 2 immunity and promotes parasitic helminth expulsion. Immunity. (2014) 41:283-95. doi: 10.1016/j.immuni.2014.06.016

30. Paclik D, Stehle C, Lahmann A, Hutloff A, Romagnani C. ICOS regulates the pool of group 2 innate lymphoid cells under homeostatic and inflammatory conditions in mice. Eur J Immunol. (2015) 45:2766-72. doi: 10.1002/eji.201545635

31. Maazi H, Patel N, Sankaranarayanan I, Suzuki Y, Rigas D, Soroosh P, et al. ICOS:ICOS-ligand interaction is required for type 2 innate lymphoid cell function, homeostasis, and induction of airway hyperreactivity. Immunity. (2015) 42:538-51. doi: 10.1016/j.immuni.2015.02.007

32. Halim TYF, Rana BMJ, Walker JA, Kerscher B, Knolle MD, Jolin HE, et al. Tissue-restricted adaptive type 2 immunity is orchestrated by expression of the costimulatory molecule OX40L on group 2 innate lymphoid cells. Immunity. (2018) 48:1195-207.e6. doi: 10.1016/j.immuni.2018. 05.003

33. Smith SG, Chen R, Kjarsgaard M, Huang C, Oliveria J-P, O'Byrne PM, et al. Increased numbers of activated group 2 innate lymphoid cells in the airways of patients with severe asthma and persistent airway eosinophilia. J Allergy Clin Immunol. (2016) 137:75-86.e8. doi: 10.1016/j.jaci.2015.05.037
34. Bartemes K, Kephart G, Fox SJ, Kita H. Enhanced innate type 2 immune response in peripheral blood from patients with asthma. J Allergy Clin Immunol. (2014) 134:671-8.e4. doi: 10.1016/j.jaci.2014.06.024

35. Liu T, Wu J, Zhao J, Wang J, Zhang Y, Liu L, et al. Type 2 innate lymphoid cells: a novel biomarker of eosinophilic airway inflammation in patients with mild to moderate asthma. Respir Med. (2015) 109:1391-6. doi: 10.1016/j.rmed.2015.09.016

36. Salimi M, Barlow JL, Saunders SP, Xue L, Gutowska-Owsiak D, Wang X, et al. A role for IL-25 and IL-33-driven type-2 innate lymphoid cells in atopic dermatitis. J Exp Med. (2013) 210:2939-50. doi: 10.1084/jem.20130351

37. Gladiator A, Wangler N, Trautwein-Weidner K, LeibundGut-Landmann S. Cutting edge: IL-17-secreting innate lymphoid cells are essential for host defense against fungal infection. J Immunol. (2013) 190:521-5. doi: 10.4049/jimmunol.1202924

38. Goto Y, Obata T, Kunisawa J, Sato S, Ivanov II, Lamichhane A, et al. Innate lymphoid cells regulate intestinal epithelial cell glycosylation. Science. (2014) 345:1254009. doi: $10.1126 /$ science. 1254009

39. Hernández PP, Mahlakoiv T, Yang I, Schwierzeck V, Nguyen N, Guendel $F$, et al. Interferon- $\lambda$ and interleukin-22 cooperate for the induction of interferon-stimulated genes and control of rotavirus infection. Nat Immunol. (2015) 16:698-707. doi: 10.1038/ni.3180

40. Sonnenberg GF, Monticelli LA, Elloso MM, Fouser LA, Artis D. CD4 ${ }^{+}$ lymphoid tissue inducer cells promote innate immunity in the gut. Immunity. (2011) 34:122-34. doi: 10.1016/j.immuni.2010.12.009

41. Zheng Y, Valdez PA, Danilenko DM, Hu Y, Sa SM, Gong Q, et al. Interleukin22 mediates early host defense against attaching and effacing bacterial pathogens. Nat Med. (2008) 14:282-9. doi: 10.1038/nm1720

42. Eberl G, Marmon S, Sunshine M-J, Rennert PD, Choi Y, Littman DR. An essential function for the nuclear receptor ROR $\gamma t$ in the generation of fetal lymphoid tissue inducer cells. Nat Immunol. (2004) 5:64-73. doi: $10.1038 /$ ni1022

43. Yokota Y, Mansouri A, Mori S, Sugawara S, Adachi S, Nishikawa S-I, et al. Development of peripheral lymphoid organs and natural killer cells depends on the helix-loop-helix inhibitor Id2. Nature. (1999) 397:702-6. doi: $10.1038 / 17812$

44. Mebius RE, Rennert P, Weissman IL. Developing lymph nodes collect $\mathrm{CD}^{+} \mathrm{CD}^{-} \mathrm{LT}^{+}$cells that can differentiate to APC, NK cells, and follicular cells but not $\mathrm{T}$ or $\mathrm{B}$ cells. Immunity. (1997) 7:493-504. doi: 10.1016/S1074-7613(00)80371-4

45. Sun Z, Unutmaz D, Zou Y-R, Sunshine MJ, Pierani A, BrennerMorton S, et al. Requirement for $\operatorname{ROR} \gamma$ in thymocyte survival and lymphoid organ development. Science. (2000) 288:2369-73. doi: $10.1126 /$ science.288.5475.2369

46. Klose CSN, Kiss EA, Schwierzeck V, Ebert K, Hoyler T, d'Hargues Y, et al. A T-bet gradient controls the fate and function of CCR6-ROR $\gamma \mathrm{t}+$ innate lymphoid cells. Nature. (2013) 494:261-5. doi: 10.1038/nature11813

47. Sciumé G, Hirahara K, Takahashi H, Laurence A, Villarino AV, Singleton KL, et al. Distinct requirements for T-bet in gut innate lymphoid cells. J Exp Med. (2012) 209:2331-8. doi: 10.1084/jem.20122097

48. Vonarbourg C, Mortha A, Bui VL, Hernandez PP, Kiss EA, Hoyler T, et al. Regulated expression of nuclear receptor ROR $\gamma t$ confers distinct functional fates to NK cell receptor-expressing ROR $\gamma \mathrm{t}+$ innate lymphocytes. Immunity. (2010) 33:736-51. doi: 10.1016/j.immuni.2010.10.017

49. Rankin L, Groom JR, Chopin M, Herold M, Walker JA, Mielke LA, et al. T-bet is essential for NKp46+ innate lymphocyte development through the Notch pathway. Nat Immunol. (2013) 14:389-95. doi: 10.1038/ni.2545

50. Bernink JH, Peters CP, Munneke M, te Velde AA, Meijer SL, Weijer K, et al. Human type 1 innate lymphoid cells accumulate in inflamed mucosal tissues. Nat Immunol. (2013) 14:221-9. doi: 10.1038/ni.2534

51. Hepworth MR, Fung TC, Masur SH, Kelsen JR, McConnell FM, Dubrot J, et al. Group 3 innate lymphoid cells mediate intestinal selection of commensal bacteria-specific CD4 ${ }^{+} \mathrm{T}$ cells. Science. (2015) 348:1031-5. doi: $10.1126 /$ science.aaa4812

52. Hepworth MR, Monticelli LA, Fung TC, Ziegler CGK, Grunberg S, Sinha $\mathrm{R}$, et al. Innate lymphoid cells regulate $\mathrm{CD} 4^{+} \mathrm{T}$-cell responses to intestinal commensal bacteria. Nature. (2013) 498:113-7. doi: 10.1038/nature12240

53. Sonnenberg GF, Monticelli LA, Alenghat T, Fung TC, Hutnick NA, Kunisawa J, et al. Innate lymphoid cells promote anatomical containment 
of lymphoid-resident commensal bacteria. Science. (2012) 336:1321-5. doi: $10.1126 /$ science. 1222551

54. Pantelyushin S, Haak S, Ingold B, Kulig P, Heppner FL, Navarini AA, et al. Rorgammat+ innate lymphocytes and gammadelta $\mathrm{T}$ cells initiate psoriasiform plaque formation in mice. J Clin Invest. (2012) 122:2252-6. doi: 10.1172/JCI61862

55. Brüggen M-C, Bauer WM, Reininger B, Clim E, Captarencu C, Steiner GE, et al. In situ mapping of innate lymphoid cells in human skin: evidence for remarkable differences between normal and inflamed skin. J Invest Dermatol. (2016) 136:2396-405. doi: 10.1016/j.jid.2016.07.017

56. Teunissen MBM, Munneke JM, Bernink JH, Spuls PI, Res PCM, te Velde A, et al. Composition of innate lymphoid cell subsets in the human skin: enrichment of NCR+ ILC3 in lesional skin and blood of psoriasis patients. $J$ Invest Dermatol. (2014) 134:2351-60. doi: 10.1038/jid.2014.146

57. Villanova F, Flutter B, Tosi I, Grys K, Sreeneebus H, Perera GK, et al. Characterization of innate lymphoid cells in human skin and blood demonstrates increase of NKp44+ ILC3 in psoriasis. J Invest Dermatol. (2014) 134:984-91. doi: 10.1038/jid.2013.477

58. Irvine AD, McLean WHI, Leung DYM. Filaggrin mutations associated with skin and allergic diseases. N Engl J Med. (2011) 365:1315-27. doi: 10.1056/NEJMra1011040

59. Palmer CNA, Irvine AD, Terron-Kwiatkowski A, Zhao Y, Liao H, Lee SP, et al. Common loss-of-function variants of the epidermal barrier protein filaggrin are a major predisposing factor for atopic dermatitis. Nat Genet. (2006) 38:441-6. doi: 10.1038/ng1767

60. Rodríguez E, Baurecht H, Herberich E, Wagenpfeil S, Brown SJ, Cordell HJ, et al. Meta-analysis of filaggrin polymorphisms in eczema and asthma: robust risk factors in atopic disease. J Allergy Clin Immunol. (2009) 123:1361-70.e7. doi: 10.1016/j.jaci.2009.03.036

61. Sandilands A, Terron-Kwiatkowski A, Hull PR, O’Regan GM, Clayton TH, Watson RM, et al. Comprehensive analysis of the gene encoding filaggrin uncovers prevalent and rare mutations in ichthyosis vulgaris and atopic eczema. Nat Genet. (2007) 39:650-4. doi: 10.1038/ng2020

62. Scheerer C, Eyerich K. Pathogenese des atopischen Ekzems. Hautarzt. (2018) 69:191-6. doi: 10.1007/s00105-018-4127-4

63. Roediger B, Kyle R, Yip KH, Sumaria N, Guy TV, Kim BS, et al. Cutaneous immunosurveillance and regulation of inflammation by group 2 innate lymphoid cells. Nat Immunol. (2013) 14:564-73. doi: 10.1038/ni.2584

64. Mjösberg JM, Trifari S, Crellin NK, Peters CP, van Drunen CM, Piet B, et al. Human IL-25- and IL-33-responsive type 2 innate lymphoid cells are defined by expression of CRTH2 and CD161. Nat Immunol. (2011) 12:1055-62. doi: 10.1038/ni.2104

65. Tait Wojno E, Monticelli L, Tran S, Alenghat T, Osborne L, Thome J, et al. The prostaglandin $\mathrm{D} 2$ receptor $\mathrm{CRTH} 2$ regulates accumulation of group 2 innate lymphoid cells in the inflamed lung. Mucosal Immunol. (2015) 8:1313-23. doi: 10.1038/mi.2015.21

66. Xue L, Salimi M, Panse I, Mjosberg JM, McKenzie ANJ, Spits H, et al. Prostaglandin D2 activates group 2 innate lymphoid cells through chemoattractant receptor-homologous molecule expressed on $\mathrm{TH} 2$ cells. $J$ Allergy Clin Immunol. (2014) 133:1184-94.e7. doi: 10.1016/j.jaci.2013.10.056

67. Salimi M, Stöger L, Liu W, Go S, Pavord I, Klenerman P, et al. Cysteinyl leukotriene E4 activates human group 2 innate lymphoid cells and enhances the effect of prostaglandin D2 and epithelial cytokines. J Allergy Clin Immunol. (2017) 140:1090-100.e11. doi: 10.1016/j.jaci.2016.12.958

68. Li M, Hener P, Zhang Z, Kato S, Metzger D, Chambon P. Topical vitamin D3 and low-calcemic analogs induce thymic stromal lymphopoietin in mouse keratinocytes and trigger an atopic dermatitis. Proc Natl Acad Sci USA. (2006) 103:11736-41. doi: 10.1073/pnas.0604575103

69. Hvid M, Vestergaard C, Kemp K, Christensen GB, Deleuran B, Deleuran M. IL-25 in Atopic Dermatitis: a Possible Link between Inflammation and Skin Barrier Dysfunction? J Invest Dermatol. (2011) 131:150-7. doi: $10.1038 /$ jid.2010.277

70. Wang Y-H, Angkasekwinai P, Lu N, Voo KS, Arima K, Hanabuchi S, et al. IL-25 augments type 2 immune responses by enhancing the expansion and functions of TSLP-DC-activated Th2 memory cells. J Exp Med. (2007) 204:1837-47. doi: 10.1084/jem.20070406

71. Fallon PG, Sasaki T, Sandilands A, Campbell LE, Saunders SP, Mangan $\mathrm{NE}$, et al. A homozygous frameshift mutation in the murine filaggrin gene facilitates enhanced percutaneous allergen priming. Nat Genet. (2009) 41:602-8. doi: 10.1038/ng.358

72. Saunders SP, Moran T, Floudas A, Wurlod F, Kaszlikowska A, Salimi M, et al. Spontaneous atopic dermatitis is mediated by innate immunity, with the secondary lung inflammation of the atopic march requiring adaptive immunity. J Allergy Clin Immunol. (2016) 137:482-91. doi: 10.1016/j.jaci.2015.06.045

73. Gasteiger G, Rudensky AY. Opinion: interactions of innate and adaptive lymphocytes. Nat Rev Immunol. (2014) 14:631-9. doi: 10.1038/ nri3726

74. Schwartz C, Moran T, Saunders SP, Kaszlikowska A, Floudas A, Bom J, et al. Spontaneous atopic dermatitis in mice with a defective skin barrier is independent of ILC2 and mediated by IL-1 $\beta$. Allergy. (2019) 74:1920-33. doi: $10.1111 /$ all.13801

75. Halim TY, MacLaren A, Romanish MT, Gold MJ, McNagny KM, Takei F. Retinoic-acid-receptor-related orphan nuclear receptor alpha is required for natural helper cell development and allergic inflammation. Immunity. (2012) 37:463-74. doi: 10.1016/j.immuni.2012.06.012

76. Dai J, Choo M-K, Park JM, Fisher DE. Topical ROR inverse agonists suppress inflammation in mouse models of atopic dermatitis and acute irritant dermatitis. J Invest Dermatol. (2017) 137:2523-31. doi: 10.1016/j.jid.2017.07.819

77. Imai Y, Yasuda K, Sakaguchi Y, Haneda T, Mizutani H, Yoshimoto T, et al. Skin-specific expression of IL-33 activates group 2 innate lymphoid cells and elicits atopic dermatitis-like inflammation in mice. Proc Natl Acad Sci USA. (2013) 110:13921-6. doi: 10.1073/pnas.1307321110

78. Oldhoff JM, Darsow U, Werfel T, Katzer K, Wulf A, Laifaoui J, et al. AntiIL-5 recombinant humanized monoclonal antibody (Mepolizumab) for the treatment of atopic dermatitis. Allergy. (2005) 60:693-6. doi: 10.1111/j.1398-9995.2005.00791.x

79. Asherson GL, Barnes RMR. Contact sensitivity in the mouse. Immunology. (1973) 24:885-94.

80. Fyhrquist N, Wolff H, Lauerma A, Alenius $\mathrm{H}$. $\mathrm{CD}^{+} \mathrm{T}$ cell migration to the skin requires $\mathrm{CD} 4^{+}$help in a murine model of contact hypersensitivity. PLoS ONE. (2012) 7:e41038. doi: 10.1371/journal.pone.0041038

81. Martin SF. Allergic contact dermatitis: xenoinflammation of the skin. Curr Opin Immunol. (2012) 24:720-9. doi: 10.1016/j.coi.2012.08.003

82. Dudeck A, Dudeck J, Scholten J, Petzold A, Surianarayanan S, Köhler A, et al. Mast cells are key promoters of contact allergy that mediate the adjuvant effects of haptens. Immunity. (2011) 34:973-84. doi: 10.1016/j.immuni.2011.03.028

83. Esser PR, Wölfle U, Dürr C, von Loewenich FD, Schempp CM, Freudenberg $\mathrm{MA}$, et al. Contact sensitizers induce skin inflammation via ROS production and hyaluronic acid degradation. PLoS ONE. (2012) 7:e41340. doi: 10.1371/journal.pone.0041340

84. Martin SF, Dudda JC, Bachtanian E, Lembo A, Liller S, Durr C, et al. Toll-like receptor and IL-12 signaling control susceptibility to contact hypersensitivity. J Exp Med. (2008) 205:2151-62. doi: 10.1084/jem.20070509

85. Weber FC, Németh T, Csepregi JZ, Dudeck A, Roers A, Ozsvári B, et al. Neutrophils are required for both the sensitization and elicitation phase of contact hypersensitivity. J Exp Med. (2015) 212:15-22. doi: $10.1084 /$ jem.20130062

86. Weber FC, Esser PR, Müller T, Ganesan J, Pellegatti P, Simon MM, et al. Lack of the purinergic receptor P2X7 results in resistance to contact hypersensitivity. J Exp Med. (2010) 207:2609-19. doi: 10.1084/jem.20092489

87. Tang L, Peng H, Zhou J, Chen Y, Wei H, Sun R, et al. Differential phenotypic and functional properties of liver-resident NK cells and mucosal ILC1s. $J$ Autoimmun. (2016) 67:29-35. doi: 10.1016/j.jaut.2015.09.004

88. Paust S, Gill HS, Wang B-Z, Flynn MP, Moseman EA, Senman B, et al. Critical role for the chemokine receptor CXCR6 in NK cell-mediated antigen-specific memory of haptens and viruses. Nat Immunol. (2010) 11:1127-35. doi: 10.1038/ni.1953

89. Rafei-Shamsabadi DA, van de Poel S, Dorn B, Kunz S, Martin SF, Klose CSN, et al. Lack of type 2 innate lymphoid cells promote a type I driven enhanced immune response in contact hypersensitivity. J Invest Dermatol. (2018) 138:1962-72. doi: 10.1016/j.jid.2018.03.001

90. Halim TYF, Steer CA, Mathä L, Gold MJ, Martinez-Gonzalez I, McNagny $\mathrm{KM}$, et al. Group 2 innate lymphoid cells are critical for the initiation of 
adaptive T Helper 2 cell-mediated allergic lung inflammation. Immunity. (2014) 40:425-35. doi: 10.1016/j.immuni.2014.01.011

91. Moro K, Yamada T, Tanabe M, Takeuchi T, Ikawa T, Kawamoto $\mathrm{H}$, et al. Innate production of $\mathrm{T}(\mathrm{H}) 2$ cytokines by adipose tissueassociated c-Kit(+)Sca-1(+) lymphoid cells. Nature. (2010) 463:540-4. doi: 10.1038/nature08636

92. Herrick CA, Xu L, McKenzie ANJ, Tigelaar RE, Bottomly K. IL13 is necessary, not simply sufficient, for epicutaneously induced Th2 responses to soluble protein antigen. J Immunol. (2003) 170:2488-95. doi: 10.4049/jimmunol.170.5.2488

93. Martin SF, Jakob T. From innate to adaptive immune responses in contact hypersensitivity. Curr Opin Allergy Clin Immunol. (2008) 8:289-93. doi: 10.1097/ACI.0b013e3283088cf9

94. Lass C, Merfort I, Martin SF. In vitro and in vivo analysis of pro- and antiinflammatory effects of weak and strong contact allergens. Exp Dermatol. (2010) 19:1007-13. doi: 10.1111/j.1600-0625.2010.01136.x

95. Dearman RJ, Kimber I. Role of $\mathrm{CD}^{+}{ }^{+} \mathrm{T}$ helper 2-type cells in cutaneous inflammatory responses induced by fluorescein isothiocyanate. Immunology. (2000) 101:442-51. doi: 10.1046/j.1365-2567.2000.01126.x

96. Ogawa A, Yoshizaki A, Yanaba K, Ogawa F, Hara T, Muroi E, et al. The differential role of L-selectin and ICAM-1 in Th1-type and Th2type contact hypersensitivity. J Invest Dermatol. (2010) 130:1558-70. doi: 10.1038/jid.2010.25

97. Bao K, Yu X, Wei X, Gui L, Liu H, Wang X, et al. Astragaloside IV ameliorates allergic inflammation by inhibiting key initiating factors in the initial stage of sensitization. Sci Rep. (2016) 6:38241. doi: 10.1038/srep38241

98. Porcelli S, Brenner MB, Greenstein JL, Terhorst C, Balk SP, Bleicher PA. Recognition of cluster of differentiation 1 antigens by human $\mathrm{CD}^{-} \mathrm{CD} 8^{-}$ cytolytic T lymphocyte. Nature. (1989) 341:447-50. doi: 10.1038/341447a0

99. Kim JH, Hu Y, Yongqing T, Kim J, Hughes VA, Nours JL, et al. CDla on Langerhans cells controls inflammatory skin diseases. Nat Immunol. (2016) 17:1159-66. doi: 10.1038/ni.3523

100. Hardman CS, Chen Y-L, Salimi M, Jarrett R, Johnson D, Järvinen VJ, et al. $\mathrm{CD} 1$ a presentation of endogenous antigens by group 2 innate lymphoid cells. Sci Immunol. (2017) 2:eaan5918. doi: 10.1126/sciimmunol.aan5918

101. Mashiko S, Mehta H, Bissonnette R, Sarfati M. Increased frequencies of basophils, type 2 innate lymphoid cells and Th2 cells in skin of patients with atopic dermatitis but not psoriasis. J Dermatol Sci. (2017) 88:167-74. doi: 10.1016/j.jdermsci.2017.07.003

102. Kim BS, Wang K, Siracusa MC, Saenz SA, Brestoff JR, Monticelli LA, et al. Basophils promote innate lymphoid cell responses in inflamed skin. $J$ Immunol. (2014) 193:3717-25. doi: 10.4049/jimmunol.1401307

103. Egawa M, Mukai K, Yoshikawa S, Iki M, Mukaida N, Kawano Y, et al. Inflammatory monocytes recruited to allergic skin acquire an antiinflammatory M2 phenotype via basophil-derived interleukin-4. Immunity. (2013) 38:570-80. doi: 10.1016/j.immuni.2012.11.014

104. Mukai K, Matsuoka K, Taya C, Suzuki H, Yokozeki H, Nishioka K, et al. Basophils play a critical role in the development of IgE-mediated chronic allergic inflammation independently of $\mathrm{T}$ cells and mast cells. Immunity. (2005) 23:191-202. doi: 10.1016/j.immuni.2005.06.011

105. Cao Q, Wang Y, Niu Z, Wang C, Wang R, Zhang Z, et al. Potentiating tissue-resident type 2 innate lymphoid cells by IL-33 to prevent renal ischemia-reperfusion injury. J Am Soc Nephrol. (2018) 29:961-76. doi: 10.1681/ASN.2017070774

106. Besnard A-G, Guabiraba R, Niedbala W, Palomo J, Reverchon F, Shaw TN, et al. IL-33-mediated protection against experimental cerebral malaria is linked to induction of type 2 innate lymphoid cells, M2 macrophages and regulatory T cells. PLoS Pathog. (2015) 11:e1004607. doi: 10.1371/journal.ppat.1004607

107. Oldenhove G, Boucquey E, Taquin A, Acolty V, Bonetti L, Ryffel B, et al. PD-1 is involved in the dysregulation of type 2 innate lymphoid cells in a murine model of obesity. Cell Rep. (2018) 25:2053-60.e4. doi: 10.1016/j.celrep.2018.10.091

108. Molofsky AB, Nussbaum JC, Liang H-E, Van Dyken SJ, Cheng LE, Mohapatra A, et al. Innate lymphoid type 2 cells sustain visceral adipose tissue eosinophils and alternatively activated macrophages. J Exp Med. (2013) 210:535-49. doi: 10.1084/jem.20121964
109. Omata Y, Frech M, Primbs T, Lucas S, Andreev D, Scholtysek C, et al. Group 2 innate lymphoid cells attenuate inflammatory arthritis and protect from bone destruction in mice. Cell Rep. (2018) 24:169-80. doi: $10.1016 /$ j.celrep.2018.06.005

110. Obata-Ninomiya K, Ishiwata K, Tsutsui H, Nei Y, Yoshikawa S, Kawano Y, et al. The skin is an important bulwark of acquired immunity against intestinal helminths. J Exp Med. (2013) 210:2583-95. doi: 10.1084/jem.20130761

111. Naik S, Bouladoux N, Linehan JL, Han S-J, Harrison OJ, Wilhelm C, et al. Commensal-dendritic-cell interaction specifies a unique protective skin immune signature. Nature. (2015) 520:104-8. doi: 10.1038/nature14052

112. Linehan JL, Harrison OJ, Han S-J, Byrd AL, Vujkovic-Cvijin I, Villarino AV, et al. Non-classical immunity controls microbiota impact on skin immunity and tissue repair. Cell. (2018) 172:784-96.e18. doi: 10.1016/j.cell.2017.12.033

113. Byrd AL, Deming C, Cassidy SKB, Harrison OJ, Ng W-I, Conlan S, et al. Staphylococcus aureus and Staphylococcus epidermidis strain diversity underlying pediatric atopic dermatitis. Sci Transl Med. (2017) 9:eaal4651. doi: $10.1126 /$ scitranslmed.aal4651

114. Ricardo-Gonzalez RR, Van Dyken SJ, Schneider C, Lee J, Nussbaum JC, Liang $\mathrm{H}-\mathrm{E}$, et al. Tissue signals imprint ILC2 identity with anticipatory function. Nat Immunol. (2018) 19:1093-9. doi: 10.1038/s41590-018-0201-4

115. Silver JS, Kearley J, Copenhaver AM, Sanden C, Mori M, Yu L, et al. Inflammatory triggers associated with exacerbations of COPD orchestrate plasticity of group 2 innate lymphoid cells in the lungs. Nat Immunol. (2016) 17:626-35. doi: 10.1038/ni.3443

116. Stehle C, Saikali P, Romagnani C. Putting the brakes on ILC2 cells. Nat Immunol. (2016) 17:43-4. doi: 10.1038/ni.3353

117. Duerr CU, McCarthy CDA, Mindt BC, Rubio M, Meli AP, Pothlichet J, et al. Type I interferon restricts type 2 immunopathology through the regulation of group 2 innate lymphoid cells. Nat Immunol. (2015) 17:65-75. doi: 10.1038/ni.3308

118. Bi J, Cui L, Yu G, Yang X, Chen Y, Wan X. NK cells alleviate lung inflammation by negatively regulating group 2 innate lymphoid cells. $J$ Immunol. (2017) 198:3336-44. doi: 10.4049/jimmunol.1601830

119. Kim HS, Jang J-H, Lee MB, Jung ID, Kim YM, Park Y-M, et al. A novel IL-10-producing innate lymphoid cells (ILC10) in a Contact Hypersensitivity Mouse Model. BMB Rep. (2016) 49:293-6. doi: 10.5483/BMBRep.2016.49.5.023

120. Madan R, Demircik F, Surianarayanan S, Allen JL, Divanovic S, Trompette A, et al. Non-redundant roles for B cell-derived IL-10 in immune counterregulation. J Immunol. (2009) 183:2312-20. doi: 10.4049/jimmunol.0900185

121. Molofsky AB, Van Gool F, Liang H-E, Van Dyken SJ, Nussbaum JC, Lee $J$, et al. Interleukin-33 and interferon- $\gamma$ counter-regulate group 2 innate lymphoid cell activation during immune perturbation. Immunity. (2015) 43:161-74. doi: 10.1016/j.immuni.2015.05.019

122. Rauber S, Luber M, Weber S, Maul L, Soare A, Wohlfahrt T, et al. Resolution of inflammation by interleukin-9-producing type 2 innate lymphoid cells. Nat Med. (2017) 23:938-44. doi: 10.1038/nm.4373

123. Wohlfert EA, Grainger JR, Bouladoux N, Konkel JE, Oldenhove G, Ribeiro $\mathrm{CH}$, et al. GATA3 controls Foxp $3^{+}$regulatory $\mathrm{T}$ cell fate during inflammation in mice. J Clin Invest. (2011) 121:4503-15. doi: $10.1172 /$ JCI57456

124. Malhotra N, Leyva-Castillo JM, Jadhav U, Barreiro O, Kam C, O’Neill NK, et al. ROR $\alpha$-expressing T regulatory cells restrain allergic skin inflammation. Sci Immunol. (2018) 3:eaao6923. doi: 10.1126/sciimmunol.aao6923

125. Cardoso V, Chesné J, Ribeiro H, García-Cassani B, Carvalho T, Bouchery T, et al. Neuronal regulation of type 2 innate lymphoid cells via neuromedin $\mathrm{U}$. Nature. (2017) 549:277-81. doi: 10.1038/nature23469

126. Galle-Treger L, Suzuki Y, Patel N, Sankaranarayanan I, Aron JL, Maazi H, et al. Nicotinic acetylcholine receptor agonist attenuates ILC2-dependent airway hyperreactivity. Nat Commun. (2016) 7:13202. doi: 10.1038/ncomms 13202

127. Klose CSN, Mahlakõiv T, Moeller JB, Rankin LC, Flamar A-L, Kabata H, et al. The neuropeptide neuromedin $\mathrm{U}$ stimulates innate lymphoid cells and type 2 inflammation. Nature. (2017) 549:282-6. doi: 10.1038/nature23676

128. Moriyama S, Brestoff JR, Flamar A-L, Moeller JB, Klose CSN, Rankin LC, et al. $\beta 2$-adrenergic receptor-mediated negative regulation of 
group 2 innate lymphoid cell responses. Science. (2018) 359:1056-61. doi: $10.1126 /$ science.aan 4829

129. Sui P, Wiesner DL, Xu J, Zhang Y, Lee J, Dyken SV, et al. Pulmonary neuroendocrine cells amplify allergic asthma responses. Science. (2018) 360:eaan8546. doi: 10.1126/science.aan8546

130. Talbot S, Abdulnour R-EE, Burkett PR, Lee S, Cronin SJF, Pascal MA, et al. Silencing nociceptor neurons reduces allergic airway inflammation. Neuron. (2015) 87:341-54. doi: 10.1016/j.neuron.2015.06.007

131. Wallrapp A, Riesenfeld SJ, Burkett PR, Abdulnour R-EE, Nyman J, Dionne D, et al. The neuropeptide NMU amplifies ILC2-driven allergic lung inflammation. Nature. (2017) 549:351-6. doi: 10.1038/nature 24029

132. Liu B, Tai Y, Achanta S, Kaelberer MM, Caceres AI, Shao X, et al. IL33/ST2 signaling excites sensory neurons and mediates itch response in a mouse model of poison ivy contact allergy. Proc Natl Acad Sci USA. (2016) 113:E7572-9. doi: 10.1073/pnas.1606608113

133. Zhao Z-Q, Huo F-Q, Jeffry J, Hampton L, Demehri S, Kim S, et al. Chronic itch development in sensory neurons requires BRAF signaling pathways. J Clin Invest. (2013) 123:4769-80. doi: 10.1172/JCI 70528
134. Oetjen LK, Mack MR, Feng J, Whelan TM, Niu H, Guo CJ, et al. Sensory neurons co-opt classical immune signaling pathways to mediate chronic itch. Cell. (2017) 171:217-28.e13. doi: 10.1016/j.cell.2017. 08.006

135. Wilson SR, Thé L, Batia LM, Beattie K, Katibah GE, McClain SP, et al. The epithelial cell-derived atopic dermatitis cytokine TSLP activates neurons to induce itch. Cell. (2013) 155:285-95. doi: 10.1016/j.cell.2013. 08.057

Conflict of Interest: The authors declare that the research was conducted in the absence of any commercial or financial relationships that could be construed as a potential conflict of interest.

Copyright $\odot 2019$ Rafei-Shamsabadi, Klose, Halim, Tanriver and Jakob. This is an open-access article distributed under the terms of the Creative Commons Attribution License (CC BY). The use, distribution or reproduction in other forums is permitted, provided the original author(s) and the copyright owner(s) are credited and that the original publication in this journal is cited, in accordance with accepted academic practice. No use, distribution or reproduction is permitted which does not comply with these terms. 